\title{
REPRESENTASI MATEMATIS SISWA SMP DALAM MENYELESAIKAN MASALAH SEGIEMPAT DITINJAU DARI PERBEDAAN JENIS KELAMIN
}

\author{
Setyaning Proboretno \\ Pendidikan Matematika, FMIPA, Universitas Negeri Surabaya \\ e-mail: setyaningproboretno@mhs.unesa.ac.id \\ Pradnyo Wijayanti \\ Pendidikan Matematika, FMIPA, Universitas Negeri Surabaya \\ $e$-mail: pradnyowijayanti@unesa.ac.id
}

\begin{abstract}
Abstrak
Representasi matematis memiliki peran penting untuk membantu siswa memahami dan menyelesaikan masalah segiempat dalam pembelajaran matematika. Siswa akan menggunakan bentuk representasi matematis yang berbeda untuk menyelesaikan suatu masalah segiempat. Hal ini memungkinkan bahwa bentuk representasi matematis yang digunakan siswa laki-laki dan siswa perempuan berbeda. Tujuan penelitian ini adalah mendeskripsikan representasi matematis siswa SMP berjenis kelamin laki-laki dan perempuan dalam menyelesaikan masalah segiempat. Penelitian ini digolongkan dalam penelitian kualitatif deskriptif dengan metode tes dan wawancara. Hasil penelitian ini menunjukkan bahwa siswa laki-laki menggunakan representasi visual-spasial dalam bentuk gambar untuk mewakili suatu objek yang ada pada tes pemecahan masalah. Selain itu, mereka menggunakan representasi visual-spasial dan representasi formalnotasional untuk mengungkapkan informasi dari suatu masalah. Selama proses penyelesaian masalah, siswa laki-laki dominan menggunakan representasi formal-notasional. Mereka juga menjelaskan secara verbal setiap langkah penyelesaian dengan rinci dan terurut. Siswa perempuan dominan menggunakan representasi formal-notasional untuk menuliskan informasi dan menyelesaikan suatu masalah. Untuk mewakili suatu objek dalam tes pemecahan masalah, mereka menggunakan representasi visual-spasial. Siswa perempuan juga menggunakan representasi verbal untuk menjelaskan setiap langkah penyelesaian masalah.
\end{abstract}

Kata Kunci: representasi matematis, masalah segiempat, jenis kelamin.

\begin{abstract}
Mathematical representation has an important role to help students understand and solve quadrilateral problems in mathematics learning. Students will use different forms of mathematical representation to solve a quadrilateral problem. This allows that the form of mathematical representation used by male and female students is different. The purpose of this study was to describe the mathematical representation of male and female junior high school students in solving quadrilateral problems. This research is classified into descriptive qualitative research using test and interview methods. The results of this study indicate that male students use visual-spatial representations in the form of images to represent an object that is in the problem solving test. In addition, they use visual-spatial representations and formal-notational representations to reveal information about a problem. During the problem solving process, dominant male students use formalnotational representation. They also explained verbally each step of the completion in detail and in order. Dominant female students use formal-notational representation to write information and solve a problem. To represent an object in a problem solving test, they use visual-spatial representations. Female students also use verbal representations to explain each step of solving problems.
\end{abstract}

Keywords: mathematical representation, quadrilateral problems, gender.

\section{PENDAHULUAN}

Saat ini di Indonesia berlaku Kurikulum 2013 sebagai acuan pembelajaran di sekolah. Dalam Kurikulum 2013 terdapat tujuan pembelajaran berikut (1) meningkatkan kemampuan intelektual, khususnya kemampuan berpikir tingkat tinggi peserta didik; (2) membentuk kemampuan peserta didik dalam menyelesaikan suatu masalah secara sistematik; (3) melatih peserta didik dalam mengomunikasikan ide-ide (Kemendikbud, 2014). Sebagai salah satu tujuan pembelajaran pada Kurikulum 2013, kemampuan menyelesaikan masalah harus dikuasai oleh setiap siswa. Penyelesaian masalah yang terus berubah setiap saat, tentu tidak mungkin dapat terwujud hanya melalui hafalan, latihan mengerjakan soal rutin, serta proses pembelajaran biasa (Yuwono, 2016: 144). Fakta 
inilah yang menjadi alasan kuat mengapa menyelesaikan masalah penting diberikan kepada siswa. Melalui pemberian masalah, siswa dapat menerapkan pengetahuan yang telah ia miliki untuk mencari solusi dari masalah yang bersifat tidak rutin.

Salah satu pihak yang menyebutkan peranan topik penyelesaian masalah dalam pembelajaran matematika adalah NCTM (National Council of Teacher of Mathematics). Menurut NCTM (2000) ada lima standar kemampuan matematika yang harus dimiliki siswa yaitu penyelesaian masalah (Problem Solving), kemampuan komunikasi (Communication), kemampuan koneksi (Connection), kemampuan penalaran (Reasioning), dan representasi (Representation). Penyelesaian masalah menjadi salah satu fokus dalam pembelajaran matematika di kelas. Hudojo (2001) menyatakan matematika yang berupa masalah yang disajikan untuk para siswa akan memberikan motivasi kepada mereka untuk mempelajari pelajaran tersebut. Oleh karena itu akan lebih baik bila mencari generalisasi dan menanamkan konsep melalui pemecahan masalah.

Selain penyelesaian masalah, representasi matematis juga memiliki peran penting dalam pembelajaran matematika. Hal ini terbukti karena representasi matematis menjadi salah satu standar kemampuan matematika NCTM. Menurut Sprague (2018: 3) "mathematical representations supplement student learning in that they provide concrete ways for students to approach mathematics concepts and make connections between their experiences and symbolic math". Representasi matematis melengkapi pembelajaran siswa karena representasi matematis memberikan cara-cara konkret bagi siswa untuk mendekati konsep-konsep matematika dan membuat hubungan antara pengalaman mereka dan matematika simbolis. Menurut Hwang et.al (2007: 197) "mathematics representation means the process of modeling concrete things in the real world into abstract concepts or symbols", yang berarti representasi matematis merupakan proses pemodelan sesuatu dari dunia nyata ke dalam konsep atau simbol yang abstrak.

Berdasarkan penelitian yang dilakukan Mairing, dkk (2012) bahwa terdapat perbedaan pemecahan masalah yang dilakukan oleh siswa laki-laki dan perempuan, meskipun perbedaan itu mungkin karena adanya perbedaan pengalaman dalam penyelesaian masalah. Perbedaan dalam menyelesaikan masalah mungkin juga akan membedakan representasi matematis yang dimunculkan siswa. Namun Zhikia (2003) menyatakan bahwa tidak ada peran gender, laki-laki atau perempuan saling mengungguli dalam matematika, bahkan perempuan bisa lebih unggul dalam berbagai bidang yang berkaitan dengan matematika. Hasil belajar matematika siswa laki-laki belum tentu lebih baik daripada perempuan dan begitu pula sebaliknya. Dari pendapat beberapa ahli tersebut belum dapat dipastikan mengenai peran jenis kelamin dalam bidang matematika. Oleh karena itu peneliti tertarik untuk mengadakan penelitian mengenai peran perbedaan jenis kelamin terhadap representasi matematis siswa.

Berdasarkan uraian yang telah dipaparkan tersebut, penelitian ini bertujuan untuk mendeskripsikan representasi matematis siswa SMP berjenis kelamin lakilaki dan perempuan dalam menyelesaikan masalah segiempat. Diharapkan penelitian ini bermanfaat untuk memberikan wawasan bagi guru untuk menyusun soal yang dapat memunculkan berbagai bentuk representasi matematis siswa dan dapat menjadi referensi dalam penelitian selanjutnya bagi peneliti lain.

\section{METODE}

Penelitian ini merupakan penelitian kualitatif yang menghasilkan data deskriptif. Subjek dalam penelitian ini adalah siswa kelas VIII-A semester ganjil SMP Negeri 1 Kediri tahun ajaran 2018/2019. Pengambilan data penelitian ini menggunakan metode tes dan wawancara. Instrumen yang digunakan dalam penelitian ini yaitu Tes Kemampuan Matematika (TKM), Tes Pemecahan Masalah (TPM), dan Pedoman Wawancara. Analisis data hasil TKM digunakan untuk menentukan subjek penelitian. Kriteria pemilihan subjek penelitian ini yaitu (1) Siswa laki-laki dan siswa perempuan masing-masing tiga orang dengan kemampuan tinggi, (2) Keenam siswa tersebut memiliki keterbukaan dan kelancaran dalam berkomunikasi, (3) Mengakui bahwa soal TPM merupakan masalah baginya. Selanjutnya analisis data TPM dengan langkah sebagai berikut (1) Jika jawaban tiga siswa dengan kelamin sejenis memunculkan bentuk representasi matematis berbeda-beda, maka setiap bentuk representasi matematis tersebut dijelaskan dan dibandingkan dengan hasil siswa yang berbeda jenis kelamin, (2) Jika dari tiga siswa dengan kelamin sejenis terdapat dua siswa yang memunculkan bentuk representasi matematis sama, maka akan dianalisis bentuk representasi matematis yang dominan muncul dan selanjutnya dibandingkan dengan hasil siswa yang berbeda jenis kelamin, (3) Jika tiga siswa dengan kelamin sejenis memunculkan bentuk representasi matematis yang sama, maka selanjutnya langsung dibandingkan dengan hasil siswa yang berbeda jenis kelamin. Data TPM dianalisis menurut indikator representasi matematis pada Tabel 1.1 berikut.

Tabel 1. Indikator Representasi Matematis dalam Menyelesaikan Masalah Segiempat

\begin{tabular}{|c|l|l|}
\hline No. & Representasi & $\begin{array}{c}\text { Bentuk-bentuk Operasional } \\
\text { (Indikator) }\end{array}$ \\
\hline 1. & $\begin{array}{l}\text { Visual-Spasial } \\
\text { (diagram, }\end{array}$ & $\begin{array}{l}\text { a. Menyajikan kembali data } \\
\text { atau informasi dari suatu }\end{array}$ \\
\hline
\end{tabular}




\begin{tabular}{|c|c|c|}
\hline & $\begin{array}{l}\text { grafik, atau } \\
\text { tabel) }\end{array}$ & $\begin{array}{l}\text { masalah ke representasi } \\
\text { diagram, grafik, atau tabel. } \\
\text { b. Menggunakan representasi } \\
\text { diagram, grafik, atau tabel } \\
\text { untuk menyelesaikan } \\
\text { masalah. }\end{array}$ \\
\hline & $\begin{array}{l}\text { Visual-Spasial } \\
\text { (gambar) }\end{array}$ & $\begin{array}{l}\text { a. Membuat gambar pola- } \\
\text { pola geometri. } \\
\text { b. Membuat gambar bangun } \\
\text { geometri untuk } \\
\text { memperjelas masalah dan } \\
\text { memfasilitasi } \\
\text { penyelesaian. }\end{array}$ \\
\hline 2. & $\begin{array}{l}\text { Formal- } \\
\text { notasional } \\
\text { (persamaan) }\end{array}$ & $\begin{array}{l}\text { a. Menuliskan rumus. } \\
\text { b. Membuat persamaan atau } \\
\text { model matematis dari } \\
\text { representasi lain yang } \\
\text { diberikan. } \\
\text { c. Penyelesaian masalah } \\
\text { dengan melibatkan } \\
\text { simbol-simbol } \\
\text { matematika. }\end{array}$ \\
\hline 3. & $\begin{array}{l}\text { Verbal (kata- } \\
\text { kata atau teks } \\
\text { tertulis) }\end{array}$ & $\begin{array}{ll}\text { a. } & \text { Menjelaskan situasi } \\
\text { masalah berdasarkan data } \\
\text { atau representasi yang } \\
\text { diberikan. } \\
\text { b. Menulis langkah-langkah } \\
\text { penyelesaian matematis } \\
\text { dengan kata-kata. } \\
\text { c. Menjawab soal dengan } \\
\text { menggunakan kata-kata } \\
\text { atau teks. }\end{array}$ \\
\hline
\end{tabular}

Setelah menganalisis data TPM, selanjutnya menganalisis data wawancara menggunakan teknik analisis Miles dan Huberman (Sugiyono, 2009).

\section{HASIL DAN PEMBAHASAN}

TKM diikuti oleh 32 siswa yang terdiri dari 12 siswa laki-laki dan 20 siswa perempuan di kelas VIII-A dengan waktu pengerjaan 40 menit. Dari hasil analisis data TKM dan pertimbangan dari guru matematika yang mengajar kelas tersebut, terpilih tiga siswa laki-laki dan tiga siswa perempuan yang memenuhi kriteria subjek penelitian. Data siswa yang tepilih menjadi subjek penelitian pada Tabel 1.2 berikut.

Tabel 1. 1 Data Subjek Penelitian

\begin{tabular}{|c|c|c|c|c|}
\hline No. & $\begin{array}{c}\text { Kode } \\
\text { Subjek }\end{array}$ & $\begin{array}{c}\text { Jenis } \\
\text { Kelamin }\end{array}$ & Skor & $\begin{array}{c}\text { Kemampuan } \\
\text { Matematika }\end{array}$ \\
\hline 1. & SP1 & Perempuan & 96 & Tinggi \\
\hline 2. & SP2 & Perempuan & 96 & Tinggi \\
\hline 3. & SP3 & Perempuan & 95 & Tinggi \\
\hline 4. & SL1 & Laki-laki & 94 & Tinggi \\
\hline 5. & SL2 & Laki-laki & 93 & Tinggi \\
\hline 6. & SL3 & Laki-laki & 92 & Tinggi \\
\hline
\end{tabular}

Selanjutnya subjek penelitian tersebut diberi TPM dan wawancara. Berikut ini dipaparkan hasil analisis dan pembahasan representasi matematis yang dominan ditunjukkan siswa laki-laki dan siswa perempuan dalam menyelesaikan masalah segiempat.

Representasi Matematis Siswa Laki-laki dalam Menyelesaikan Masalah Segiempat

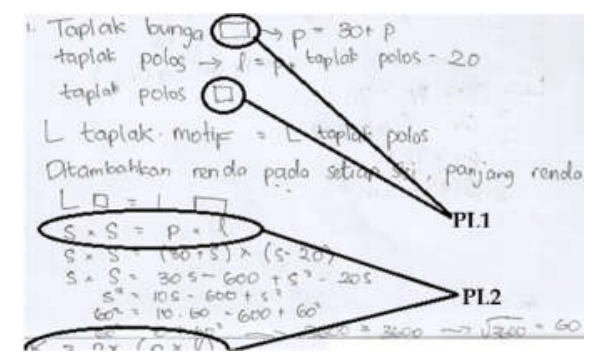

Gambar 1. 1 Penyelesaian Masalah Siswa Laki-laki

Siswa laki-laki menuliskan informasi yang diketahui bahwa ukuran luas taplak motif dan luas taplak polos adalah sama pada lembar jawabannya. Tidak hanya itu, mereka juga menuliskan apa yang ditanyakan pada soal. Setelah mengungkapkan informasi yang diketahui pada soal, siswa laki-laki menggambar persegipanjang untuk taplak motif bunga dan gambar persegi untuk taplak polos (Gambar 1.1 kode PL1). Gambar yang dibuat tersebut menunjukkan bahwa mereka menggunakan representasi visual-spasial yang sesuai dengan indikator membuat gambar pola-pola geometri.

Untuk menyelesaikan masalah tersebut, siswa laki-laki membuat bentuk persamaan antara luas persegi dan luas persegipanjang (Gambar 1.1 kode PL2). Langkah selanjutnya mereka mensubstitusi apa yang diketahui pada soal ke dalam persamaan tersebut. Dari persamaan tersebut, didapat nilai s adalah 60. Dan langkah terakhir mencari keliling taplak motif bunga hingga diperoleh hasilnya 7200 $\mathrm{cm}$. Namun hasil akhir yang didapat ini bukanlah hasil yang benar untuk menjawab masalah tersebut. Hal ini dikarenakan siswa laki-laki kurang teliti saat menghitung keliling.

Pemisalan dan persamaan yang dibuat siswa laki-laki menunjukkan bahwa mereka menggunakan representasi formal-notasional dalam penyelesaian masalah. Representasi formal-notasional tersebut sesuai dengan indikator menuliskan rumus dan membuat persamaan atau model matematis dari representasi matematis lain yang diberikan. Namun dalam proses menyelesaikan masalah ditemukan bahwa siswa laki-laki kurang teliti dalam perhitungan. Hal ini sesuai dengan pendapat Krutetskii (Rizal, 2011) bahwa laki-laki kurang baik dalam ketelitian dan kecermatan jika dibanding perempuan.

Berdasarkan analisis hasil TPM tersebut, siswa laki-laki dominan menggunakan representasi visual-spasial dan 
representasi formal-notasional. Representasi visual-spasial yang dominan digunakan oleh siswa laki-laki adalah gambar. Hal ini ditunjukkan dengan hasil gambar persegipanjang dan persegi untuk mewakili suatu objek pada masalah. Ini sesuai dengan pendapat Guler \& Ciltras (2011) bahwa representasi visual dianggap yang efisian untuk menyelesaikan masalah.

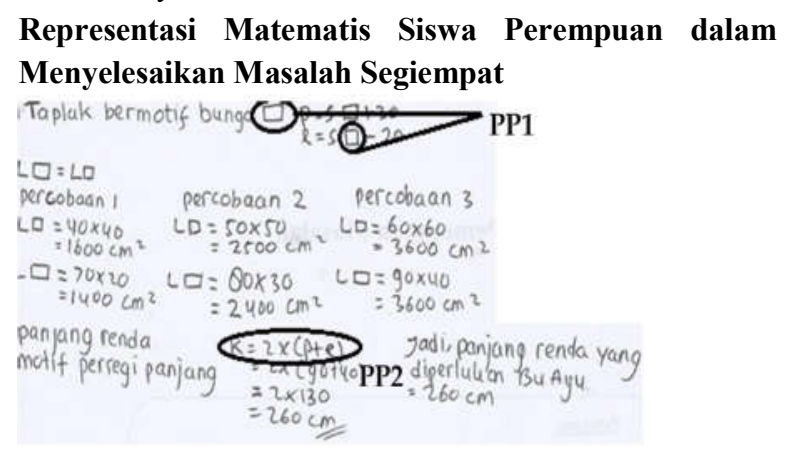

Gambar 1. 2 Penyelesaian Masalah Siswa Perempuan

Siswa perempuan menuliskan informasi yang didapat dari soal dalam bentuk pemisalan dan gambar. Untuk mewakili taplak bermotif bunga, mereka membuat gambar persegipanjang. Sedangkan taplak motif polos digambarkan dengan bentuk persegi (Gambar 1.2 kode PP1). Gambar persegi dan persegipanjang yang dibuat siswa perempuan ini menunjukkan bahwa mereka menggunakan representasi visual-spasial. Hal ini memenuhi indikator membuat gambar pola-pola geometri.

Selanjutnya siswa perempuan menuliskan beberapa percobaan untuk menemukan ukuran taplak bermotif bunga yang berbentuk persegipanjang. Hingga pada percobaan ke 3, mereka menemukan ukuran taplak bermotif bunga yaitu $90 \times 40 \mathrm{~cm}$. Langkah berikutnya mencari panjang renda yang dibutuhkan dengan menghitung keliling taplak meja tersebut dan hasilnya 260 cm (Gambar 1.2 kode PP2).

Pada percobaan yang dibuat siswa perempuan tersebut menunjukkan bahwa mereka menggunakan beberapa simbol matematika dan rumus luas persegi dan persegipanjang. Begitu pun saat mencari panjang renda, mereka menggunakan rumus keliling persegipanjang. Hal ini berarti siswa perempuan menggunakan representasi formal-notasional dengan indikator menuliskan rumus dan menyelesaikan masalah dengan melibatkan simbol-simbol matematika.

Siswa perempuan membuat gambar persegi dan persegipanjang untuk mewakili suatu objek. Hal ini sesuai dengan pendapat Goldin (2002: 208) bahwa representasi dapat mewakili sesuatu yang lain dalam beberapa cara. Dengan membuat gambar-gambar tersebut, menunjukkan bahwa siswa perempuan menggunakan representasi visualspasial dalam penyelesaian masalah.

Gambar dan persamaan yang digunakan oleh siswa perempuan bertujuan untuk menerjemahkan hal yang konkret menjadi simbol matematika. Ini sesuai dengan yang diungkapkan Hwang, dkk (2007: 192) bahwa dalam psikologi, representasi merupakan proses memodelkan dari dunia nyata menjadi konsep abstrak.

\section{PENUTUP}

\section{Simpulan}

Berdasarkan analisis data dan pembahasan yang telah dipaparkan, peneliti membuat simpulan mengenai representasi matematis siswa SMP berjenis kelamin lakilaki dan perempuan dalam menyelesaikan masalah segiempat sebagai berikut.

1. Representasi matematis siswa SMP berjenis kelamin laki-laki dalam menyelesaikan maaslah segiempat

Siswa laki-laki menggunakan representasi visualspasial untuk menuliskan apa yang diketahui dari soal. Mereka menggambar bangun persegipanjang dan persegi untuk menjelaskan bentuk suatu objek. Selanjutnya siswa laki-laki menggunakan representasi formal-notasional untuk mencari jawaban akhir. Representasi formalnotasional yang digunakan berupa rumus dan simbolsimbol matematika. Hasil akhir dari masalah yang mereka kerjakan seringkali disajikan dengan simbol matematika dan suatu kalimat. Kalimat ini merupakan salah satu contoh bentuk representasi verbal. Hasil wawancara yang telah dilakukan juga menunjukkan bahwa siswa laki-laki menggunakan representasi verbal untuk menyelesaikan masalah.

\section{Representasi matematis siswa SMP berjenis kelamin perempuan dalam menyelesaikan maaslah segiempat}

Siswa perempuan menunjukkan penggunaan representasi visual-spasial mereka dengan membuat gambar persegipanjang dan persegi. Dengan gambar tersebut, mereka dapat mewakili keadaan yang dimaksud dari masalah tersebut. Selanjutnya siswa perempuan menggunakan beberapa rumus dan simbol matematika untuk mendapatkan jawaban dari masalah tersebut. Hal ini menunjukkan bahwa mereka menggunakan representasi formal-notasional. Penggunaan representasi formalnotasional juga terlihat saat siswa perempuan menyelesaikan bentuk persamaan. Setelah menyelesaikan tes tertulis, siswa perempuan juga menjelaskan penyelesaian masalah secara verbal dalam wawancara. Setiap langkah penyelesaian disebutkan dengan urut dan jelas.

\section{Saran}

Berdasarkan hasil penelitian dan refleksi penelitian yang telah dipaparkan, peneliti memberikan saran bagi peneliti lain yang akan melakukan penelitian yang relevan untuk menyusun instrumen Tes Pemecahan Masalah 
dengan soal open-ended agar bentuk representasi matematis yang ditunjukkan siswa lebih variatif.

\section{DAFTAR PUSTAKA}

Goldin, G.A. 2002. Representation in Mathematical Learning and Problem Solving. https://books.google.co.id/books?hl=id\&lr=\&id=LD GRAgAAQBAJ\&oi=fnd\&pg=PA197\&dq=Represe ntation+in+Mathematical+Learning+and+Problem+ Solving\&ots $=$ ODFVla7qf3\&sig $=0$ tblQElbTaBoh8Q EcN7dQ8T093w\&redir esc $=\mathrm{y} \# \mathrm{v}=$ onepage \&q $=$ Repr esentation \%20in\%20Mathematical\%20Learning\%2 0and $\% 20$ Problem $\% 20$ Solving \&f $=$ false Diakses pada 8 November 2018

Guler, G \& Ciltras, A. 2011. The Visual Representation Usage Levels of Mathematics Teachers and Students in Solving Verbal Problems. International Journal of Humanities and Sosial Science. Vol. 1 (11) pg. 145154

Hudojo, Herman. 2001. Pengembangan Kurikulum dan Pembelajaran Matematika. Malang: Universitas Negeri Malang

Hwang, et.al. 2007. Multiple Representation Skills and Creativity Effects on Mathematical Problem Solving using a Multimedia Whiteboard System. Educational Technology \& Society, 10 (2), 191212

Kemendikbud. 2014. Panduan Penguatan Proses Pembelajaran Sekolah Menengah Pertama.
(https://www.academia.edu/8945651/Pandua $\underline{\text { n_Penguatan_pembelajaran) }}$ Diakses pada 8 November 2018

Mairing, dkk. 2012. Perbedaan Profil Pemecahan Masalah Peraih Medali OSN Matematika Berdasarkan Jenis Kelamin. Jurnal Ilmu Pendidikan. Vol. 18, No. 2

NCTM. 2000. Principles and Standars for School Mathematics. United States of America

Rizal, Muh. 2011. Proses Berpikir Siswa Sekolah Dasar Melakukan Estimasi dalam Pemecahan Masalah Berhitung Ditinjau dari Kemampuan Matematika dan Jenis Kelamin. Disertasi tidak diterbitkan. PPs: Universitas Negeri Surabaya

Sprague, Savannah Layne. 2018. Using Mathematical Representations in the Classroom and the Effects on Student Learning. Riverside: University Honors

Sugiyono. 2009. Metode Penelitian Kuantitatif, Kualitatif, dan RED. Bandung: Alfabeta

Yuwono, Aris. 2016. Problem Solving dalam Pembelajaran Matematika. UNION: Jurnal Pendidikan Matematika. Vol. 1, No. 1, pp. 143156

Zhikia, Y. 2003. Gender Differences in Mathematics Learning. School Science in Mathematics. 110 (3): 115-117 